\title{
Media Messages About Cancer: What Do People Understand?
}

\author{
KATHLEEN M. MAZOR, \\ University of Massachusetts Medical School, and Meyers Primary Care Institute, Worcester, \\ Massachusetts, USA \\ JOSEPHINE CALVI, \\ Kaiser Permanente, Atlanta, Georgia, USA
}

REBECCA COWAN,

Kaiser Permanente, Honolulu, Hawaii, USA

MARY E. COSTANZA,

University of Massachusetts Medical School, Worcester, Massachusetts, USA

PAUL K. J. HAN,

Center for Outcomes Research and Evaluation, Portland, Maine, USA

SARAH M. GREENE, Group Health Research Institute, Seattle, Washington, USA

LAURA SACCOCCIO, Meyers Primary Care Institute, Worcester, Massachusetts, USA

ERICA COVE, Meyers Primary Care Institute, Worcester, Massachusetts, USA

DOUGLAS ROBLIN, and

Kaiser Permanente, Atlanta, Georgia, USA

\section{ANDREW WILLIAMS}

Kaiser Permanente, Honolulu, Hawaii, USA

\begin{abstract}
Health messages on television and other mass media have the potential to significantly influence the public's health-related knowledge and behaviors, but little is known about people's ability to comprehend such messages. To investigate whether people understood the spoken information in media messages about cancer prevention and screening, we recruited 44 adults from 3 sites to view 6 messages aired on television and the internet. Participants were asked to paraphrase main points and selected phrases. Qualitative analysis methods were used to identify what content was correctly and accurately recalled and paraphrased, and to describe misunderstandings and misconceptions. While most participants accurately recalled and paraphrased the gist of the messages used here, overgeneralization (e.g., believing preventative behaviors to be more protective than stated), loss of details (e.g., misremembering the recommended age for screening) and confusion or misunderstandings around specific concepts (e.g., interpreting "early stage" as the stage in one's life rather than cancer stage) were common. Variability in the public's ability to understand spoken media messages may limit the effectiveness of both pubic health campaigns and provider-patient communication. Additional research is needed to identify message characteristics which enhance understandability and improve comprehension of spoken media messages around cancer.
\end{abstract}

Address correspondence to Kathleen M. Mazor, Meyers Primary Care Institute, 630 Plantation Street, Worcester, MA 01605, USA. Kathy.Mazor@meyersprimary.org. 


\section{Introduction}

Local and national television news programs often air stories on health (Gantz \& Wang, 2009; Pribble et al., 2006; Wang \& Gantz, 2007, Wang \& Gantz, 2010) which have the potential to significantly influence the public's health-related knowledge, beliefs and even subsequent communication behaviors (Southwell \& Torres, 2006). People watch such news stories because they expect to be informed by them (Southwell, Hwang, \& Yzer, 2008), and television is an important source of health information for most Americans (Gallup Organization, 2002), especially those without regular access to a physician (Yanovitzky \& Blitz, 2000), and older, low income adults (Weiss, Reed, \& Kligman, 1995).

Cancer is a leading cause of morbidity and mortality in the United States (American Cancer Society, 2008). Many cancers are related to modifiable risk factors, such as diet, tobacco use, obesity, and lack of physical exercise and mortality from certain cancers can be reduced through screening and early detection. Furthermore, many cancer concepts and vocabulary are difficult, unfamiliar, and poorly understood by lay people.(Davis et al., 2001; Friedman, Corwin, Dominick, \& Rose, 2009; Savage \& Clarke, 1998; Silverman et al., 2001; Williams, Davis, Parker, \& Weiss, 2002). Communication about risk, an essential concept in cancer prevention, is particularly difficult (Carlsson \& Strang, 1997; Fischhoff, 1999; Kaphingst, Rudd, Dejong, \& Daltroy, 2005; Klein \& Stefanek, 2007; Roche et al., 1998; Salant, Ganschow, Olopade, \& Lauderdale, 2006; Slovic, 2000). News coverage can effectively publicize particular cancer issues, and contribute to changes in preventive behavior, cancer knowledge, and information seeking (Niederdeppe, Frosch, \& Hornik, 2008; Schroy et al., 2008; Yanovitzky \& Blitz, 2000). However, aside from research on the effectiveness of anti-smoking media campaigns, there has been little research into whether media messages relating to cancer prevention and screening are well understood by the general public. Given the prevalence and potential impact of media reports on cancer, it is not surprising that there have been calls for research to improve reporting in this area (Hesse, 2009). Empirical studies of how members of the general public respond to specific messages are an important step towards designing new, more effective messages (Schofield \& Butow, 2004; Schroy et al., 2008).

It is now widely recognized that a significant proportion of Americans have low levels of health literacy with respect to written materials, as documented by the recent Institute of Medicine report on the topic (Institute of Medicine, 2004) and low health literacy has been identified as a national priority (Carmona, 2006). Although most of the attention to date has focused on patients' difficulties with written materials, health literacy is a multi-dimensional set of skills and abilities, which includes facility with spoken messages (Institute of Medicine, 2004; Baker, 2006). The potential negative impact of low health literacy therefore extends beyond written health messages, to spoken messages as well. However, with few exceptions, (Rosenfeld et al., 2010; Roter, Erby, Larson, \& Ellington, 2009; Roter, Erby, Larson, \& Ellington, 2007; Rubin, Hafer, \& Arata, 2000) research into health literacy with respect to spoken information has been absent. This is an important gap, as a better understanding of the factors that drive comprehension of spoken messages about cancer prevention and screening has the potential to yield practical benefits.

There are important differences between written and spoken messages. What makes a message readable may not make it listenable (Rubin, Hafer, \& Arata, 2000). Written and spoken messages differ the extent to which the message recipient can control the pacing, amount, and review of the information presented, with each of these being more easily under the recipient's control when the message is written (Wilson \& Wolf, 2009). Conversely, spoken messages have the obvious advantage of not requiring reading competency. But there are commonalities between written and spoken messages- regardless of channel, the recipient must have some 
relevant background knowledge for comprehension to occur. That is, the recipient must have some understanding of the meaning of the specific words used and concepts referred to (Graesser, Millis, \& Zwaan, 1997; Kintsch, 1988; Kintsch, 1998). Thus there is a second important gap in the health literacy research conducted to date: an absence of attention to the issue of comprehension of either written or spoken health messages, especially in applied settings. Findings from the few studies that have been conducted on comprehension in the context of health suggest that terms critical to decision-making around cancer screening and treatment are often misunderstood (Armstrong \& Murphy, 2008; Kilbridge et al., 2009). Others have found similarly poor comprehension of commonly used terms in other chronic conditions such as diabetes (Castro, Wilson, Wang, \& Schillinger, 2007), and health care report cards intended for the public (Jewett \& Hibbard, 1996).

More information on the specific misunderstandings and knowledge gaps that patients and members of the public face will be helpful on a number of levels. Clinicians, designers of public health programs (Kreuter, 1999), health service trialists (Schofield \& Butow, 2004), and media outlets (Vernon, 1999; Viswanath, 2005) can use this knowledge to develop more comprehensible messages. An understanding of the individual differences that are associated with variation in comprehension will help researchers and clinicians identify those patients who are most likely to benefit from decision support materials and procedures (Carlsson \& Strang, 1997). An initial step toward achieving these benefits will be to identify the concepts and vocabulary that lay people tend to misunderstand.

Our research group is currently developing an instrument to assess comprehension of spoken information about cancer prevention and screening. As part of the test development process we sought to identify specific terms and concepts related to cancer prevention and screening that lay people would be likely to encounter in daily life. We therefore undertook the formative, descriptive research described here, in an effort to identify potentially confusing terms and concepts that could form the basis of test items to be administered in a subsequent, quantitative study. Specifically, we sought to identify misconceptions and misunderstandings of key concepts and terms related to cancer prevention and screening as conveyed in media messages sampled from television and the internet.

\section{Methods}

\subsection{Sample and Recruitment}

This study was conducted within the Cancer Research Network, a consortium of research organizations affiliated with non-profit integrated healthcare delivery systems and the National Cancer Institute. Adults aged 40-70 were recruited from three sites: Kaiser Permanente Georgia, Kaiser Permanente Hawaii, and Fallon Community Health Plan. Beyond age, additional eligibility criteria were ability to speak and understand English, and absence of physical or psychological limitations that would interfere with participating in a 1 hour study session. No criteria with respect to participants' experience with cancer were used. A letter of invitation was mailed to a random sample of eligible health plan members at each site. The letter described the study, and offered a $\$ 25$ stipend for participation. Using geocoded address lists, selection was stratified by educational level (defined by the percentage of residents with a high school education or less), in order to optimize sampling across educational levels.

\subsection{Study Materials}

Six video clips that contained content on screening or prevention of skin, prostate, colon, cervical, and breast cancers, as well as cancer in general, were selected for the study. Clips were selected to provide variety in content and concepts presented, as well as a variety of familiar formats and sources. Clips focuses on on breast, prostate, cervical and skin cancer 
were selected because of the prevalence of these cancers, the availability of screening, and the existence of behavioral risk factors. Four television clips were selected and two internet-only clips were selected because the team believed that lay people would be more likely to encounter television-based video than internet-based video in their daily lives. This belief was based on the fact that although use of the internet to find health information is increasing, much of the information on the internet is written rather than video. The selected clips therefore were a convenience sample of videos which the team judged to be typical of a range of formats and sources which were available to the public at that time. The sample of clips was not representative of all available videos. All of the clips were downloaded from the internet between March 9 and May 8, 2008. Details on the clips used are provided in Table 1.

From each video transcript, the team identified two sentences a priori, and selected a key word or phrase in each sentence as important to understanding critical concepts in cancer prevention or screening. Final selection decisions occurred after discussion, and were made with the consensus of the entire team.

\subsection{Interview Procedures}

Interviews were conducted in 1:1 in-person study sessions, lasting approximately 1 hour. After obtaining informed consent for participation, the interviewer administered a small number of questionnaire items, including the single item literacy screener (Morris, MacLean, Chew, \& Littenberg, 2006), and demographic questions. The interviewer then played the first video clip for the participant. All videos were played on a laptop computer; headphones were optional. When the video ended, the interviewer asked the participant to "please tell me, in your own words, what was the main point of this clip?" After the participant responded, the interviewer then read one of the sentences selected from the transcript of the just-viewed video, and again asked the participant to "tell me in your own words what the sentence means". Finally, she read the selected word or phrase from the sentence, and asked the participant to "tell me in your own words what the word ___ means". Interviewees' responses were transcribed in their entirety.

\subsection{Qualitative Analysis}

Interviewees' responses for each of questions about main points and the selected words and phrases were analyzed separately, as described below.

Analysis of paraphrases of main points-The study team reviewed the transcripts and visual images, and developed a detailed listing of the information conveyed in each video clip. The team then developed a coding scheme for categorizing participants' responses according to the content referred to and the level of specificity. An example showing a portion of the coding scheme for one of the clips is provided in Table 2. Four investigators reviewed the content code list extracted from each transcript and the visual review of the video, and confirmed whether all content had been identified and was included on the content code list. All interviewee responses describing the main points of the video clip were reviewed and coded using this coding scheme. Responses referring to information not in the video were also documented. Participants' responses were also coded as accurate, inaccurate, or questionable with respect to the information conveyed in the video. Statements coded as either questionable or inaccurate with respect to the clip were reviewed by at least one physician reviewer who determined accuracy; if needed a second physician reviewer was also consulted. Two team members coded each response independently; disagreements were identified and discussed until consensus was reached. Comments referring to personal experiences were omitted from the analysis. All coded responses were then reviewed by at least one additional team member who checked accuracy of coding and identified any items needing additional team review or clinical review. 
Analysis of paraphrases of key words and phrases-The coding team summarized the results of each word/phrase definition analysis, categorizing the definitions based on the content of the original and the paraphrase, and noting the incorrect definitions.

The study was reviewed and approved by the Institutional Review Boards of each of the participating organizations.

\section{Results}

A total of 44 adults completed interviews. Interviewee characteristics are summarized in Table 3 .

Results of the qualitative analysis of the interviewees' paraphrasing of the main points of the video clips are summarized in Table 4. Gist has been defined as the fundamental qualitative, "bottom-line meaning of information," as opposed to its "verbatim," or precise, quantitative, but surface meaning (Reyna, 2008). Overall, most participants in this study did recall and understand the gist of the six video clips studied here. For instance, many interviewees correctly referred to the risk factors mentioned in the clips (such as family history, being overweight, or being inactive), to preventive behaviors (being active, limiting sun exposure, and eating a healthy diet), the importance of screening (women should have mammograms, Pap tests; people should have colonoscopies, and examine their skin), and the importance of catching cancer early. However, we also identified numerous misunderstandings. A number of interviewees over-generalized from the information presented, suggesting that cancers are more prevalent, that risks are higher, that screening should be more often, that screening is more effective, that risk factors are causative, that dietary changes should be more extreme, or that preventative behaviors are more protective against more cancers than was conveyed in the video. In addition, some interviewees confused screening with treatment.

Interviewees also held a number of more specific misconceptions. For example, we noted references to "catching" cancer, confusion about the term "early stage" (i.e., interpreting the term as referring to the stage in a person's life, rather than an early stage in the development of the disease) and referring to the danger of colon polyps breaking loose. Interviewees also misremembered specifics such as relevant age ranges, specific percentages, recommended timing or intervals for screening, or the type of cancer associated with a specific risk factor. Also noted were confusion as to whether screening was appropriate for both men and women, with some interviewees referring specifically to "men" needing to be screened for colon cancer.

Results of the qualitative analysis of interviewees' paraphrases of selected key words are summarized in Table 4. The second column of this table provides examples intended to illustrate the variety of responses recorded. For each of the key words included in this study, at least some interviewees also responded that they were not sure, were confused or simply didn't know what the word or phrase meant.

\section{Discussion and Conclusions}

\subsection{Discussion}

The results of these interviews with a diverse sample of adult health plan members from three sites around the country suggest that spoken messages about cancer prevention and screening are frequently misunderstood. Comprehension of key concepts was found to be highly variable. While some participants expressed a clear understanding of the "gist" of the messages presented in the video clips used here, a number of significant "verbatim"-level misunderstandings were noted. 
Most participants seemed to understand that their actions can affect their health, and that screening is important. However, some over-estimated the impact of healthy behavior and screening practices, overstating their protective value. Some also over-estimated the dangers of engaging in behaviors that are associated with increased risk, and thought that "at risk" meant at very high risk. Overall, the misunderstandings and misconceptions found here suggest that patients' decision-making about health behaviors and various cancer screening procedures may be based on insufficient understanding of the scientific evidence and rationale supporting these behaviors. However, although many of these cases showed deficits in people's verbatim understanding, overall people tended to understand and recall the gist of the information; thus such verbatim misunderstandings may not necessarily function as barriers to preventative behaviors or to screening uptake. Furthermore, some misunderstandings could have paradoxically beneficial outcomes. Over-estimates of individual risk and the effectiveness of screening, as well as inappropriate inferences about the causal influence of risk factors might have the net effect of increasing healthy behaviors and participation in screening. Nevertheless, to the extent that inaccurate risk perceptions and causal inferences represent misunderstandings, they are ethically problematic and could have other negative effects, including diminishing people's sense of well being, and promoting feelings of helplessness. There is some evidence from the mammography literature that perceived high risk may increase anxiety to the point that screening activity may be blocked (Lerman \& Schwartz, 1993). This study did not allow us to assess the presence or direction of such effects.

The misconceptions and oversimplifications of the sort described here could also have other negative effects. For example, if a person misinterprets a news report as establishing a causal relationship (e.g., a sedentary job causes prostate cancer) and he is aware of one or more exceptions to this relationship (a friend who had a job which entailed significant physical activity developed prostate cancer), he may completely discount the report. Such discounting could also be generalized, leading to the conclusion that all reports should be ignored, as "they just don't know". Thus the problem of discounting may be exacerbated by misunderstanding. Other misconceptions about disease causation-e.g., viewing risk factors or health risk behaviors as excessively deterministic —also have the potential to cause people who are diagnosed with cancer to feel unduly responsible and even guilty about developing the disease. This danger has been noted previously in studies of women's mental models of breast cancer (Silverman et al., 2001).

While this study was not designed to identify the factors that affect comprehension of spoken messages about cancer screening and prevention, transcription and repeated review of the video clips used in this study suggests that these typical messages were less than ideal. Key messages sometimes contained inaccuracies. An example of this was the reference in the video on skin cancer to advising a physician examination of a mole if the diameter is one half inch to one inch, when the standard recommendation is one quarter inch diameter. In other instances, speakers seemed to be sensationalizing or overstating the facts. An example of this was the news anchor's statement on the prostate cancer video "If you're one of the millions of American men working all day at a desk job, you may want to get up and take a walk after you watch this segment. Sitting can increase your risk of prostate cancer." We also found instances where the discussion overall suggested a lack of clarity on the key concepts. An example of this is the breast cancer controversy video, in reaction to the USPSTF recommendation that women age 40 to 49 talk with their PCP about annual mammography, the expert stated "Mammograms are a very, very low-risk procedure, as you and I both know...I really don't see the downside they are talking about, and they actually didn't prove it in their paper." Inaccuracies and other shortcomings of television news coverage of health stories have been reported previously, suggesting that these clips were not atypical in this regard (Pribble et al., 2006). As most of the video clips used in this study were not produced as patient education materials, this is not surprising, but inaccuracies in their content may have encouraged some of the misconceptions 
found here. Similarly, inaccuracies reported in prior media reports that these participants had been exposed to previously may also have contributed to these misconceptions, by contributing to inaccurate background knowledge. Another possible contributor to poor comprehension of the information for some participants may be the level of detail provided. While the video clips used in this study were brief, most contained several pieces of detailed information, and the volume of information may have exceeded people's capacity to process and remember it clearly (Reyna, 2008).

This study was not designed to elucidate cognitive processes, but rather to identify possible misunderstandings and knowledge gaps that could impact comprehension of any health message with similar content, regardless of channel or context. Thus while inattention or forgetting may have contributed to inaccurate reporting of details such as those reported here, we also identified misunderstandings that appeared to be unrelated to memory or attention.

The plethora of recent research on health literacy has drawn attention to problems that many patients experience in understanding written materials. The findings presented here highlight the challenges inherent in understanding spoken health information. Simply putting a message into spoken form will not ensure successful communication of the message, and thus may not improve communication with people with limited health literacy. Furthermore, the features that determine the listenability of spoken messages are not the same features that determine readability of written messages (Rubin, Hafer, \& Arata, 2000). Both written and spoken messages have associated advantages and disadvantages. Written materials allow self-pacing, control of order, and review of content, and may minimize distractions, at least those distractions inherent in the materials (Mayer, Hegarty, Mayer, \& Campbell, 2005; Wilson \& Wolf, 2009). However, video offers obvious advantages for depicting action or procedural information, and require no reading skill (Wilson \& Wolf, 2009). It has also been argued that listening facilitates uptake of gist and pragmatic inferences that follow from gist, while reading facilitates selective processing control of attention (Rubin, Hafer, \& Arata, 2000). At present, it is not clear that video or audio presentation of information is superior to print, and there is some evidence that print may be advantageous, as least in some situations (Campbell, Goldman, Boccia, \& Skinner, 2004; Corston \& Colman, 1997; Mayer, Hegarty, Mayer, \& Campbell, 2005). Study of the comparative effectiveness of the two modes of communicating important health information, and of the mediating or moderating effects of reading competency and background knowledge, is an area worthy of further investigation.

This study has several implications for practitioners. Prior research suggests that physicians are not accurate judges of their patients' print literacy skills (Rogers, Wallace, \& Weiss, 2006). It would not be surprising to find that practitioners tend to over-estimate their patients' literacy with respect to spoken information as well, especially if there is a common underlying factor contributing to both types of literacy - i.e., insufficient background knowledge and a misunderstanding of core concepts.

Many providers tailor their communication efforts in an effort to meet the needs of their patients, using simple terms and speaking slowly when they anticipate a patient may find it hard to understand (Schwartzberg, Cowett, VanGeest, \& Wolf, 2007), but with few exceptions (see for instance, Nekhlyudov \& Braddock, 2009) providers have had little direction on exactly how to explain complex concepts related to cancer screening and prevention. In the area of health literacy, toolkits have been developed and disseminated which contain lists of difficult terms and suggested phrasing that can be used to enhance written materials (Ripath, Greene, $\&$ Weise, 2007). The findings presented here, together with findings from other studies of patients' understandings (e.g., Kilbridge et al., 2009) could be used as the first step towards a comparable "listenability" toolkit. Such a toolkit could offer specific recommendations for both providers and the media to more effectively communicate with lay people about complex 
topics. For now, these findings highlight that providers should not assume that patients understand even apparently simple medical terms and concepts, and insteadshould routinely check understanding, and reinforce key points.

This study has limitations. Because the educational level of study participants was relatively high, with only a few participants having a high school education or less, our results provide little insight into the sorts of misunderstandings and misconceptions that people with little education are likely to have. Still, studies have shown that education and functional health literacy are not completely correlated, and that well-educated populations may still struggle with health-related concepts. We also did not assess participants' prior exposure to health information, which could have had a substantial influence on how they interpreted and processed newly encountered health messages, for instance if a new message conflicted or reinforced earlier messages. While the study team concurred that the six video clips used in this study could be considered typical of the sorts of videos that people might encounter in their day to day life, these clips are not a representative sample of all available video clips, and different results might have been obtained if a different set of clips were used. Other approaches to soliciting participants' understanding and other approaches to the analysis of the transcripts might have resulted in different conclusions. Finally, this study was designed to identify misconceptions and misunderstandings, not to estimate prevalence of these, or to test associations between education, race, ethnicity and other variables. Future studies are needed to test specific hypotheses in these areas.

\subsection{Conclusion}

Most study participants understood the gist of six different video clips about cancer prevention and screening. However, several key concepts were misunderstood by at least some participants, and message details were often misunderstood or misremembered. When present, such misunderstandings of key concepts may influence people's decision-making about cancer screening and prevention. More research is needed to identify the factors that enhance or impede comprehension of spoken health messages, and to describe the prevalence and impact of poor comprehension in spoken media messages and clinical encounters.

When talking with patients about cancer prevention and screening, providers should not assume that patients will understand key concepts, even with care to avoid jargon. Checking comprehension of key points is advised. While the focus of this study was media messages about cancer prevention and screening, these results have important implications for interpersonal communication as well, as they highlight that spoken messages are susceptible to misunderstanding much as written materials are.

\section{Acknowledgments}

The study reported here was funded by a grant from the National Cancer Institute (2 U19 CA079689-09). It was conducted within the context of a core project of to the HMORN Cancer Research Network, Health Literacy and Cancer Prevention: Do People Understand What They Hear?

\section{References}

American Cancer Society. Cancer Facts \& Figures 2008. Atlanta: American Cancer Society; 2008.

Armstrong N, Murphy E. Weaving meaning? An exploration of the interplay between lay and professional understandings of cervical cancer risk. Social Science and Medicine 2008;67(7):1074-1082. [PubMed: 18640758]

Baker DW. The Meaning and the Measure of Health Literacy. Journal of General Internal Medicine 2006;21:878-883. [PubMed: 16881951] 
Campbell FA, Goldman BD, Boccia ML, Skinner M. The effect of format modifications and reading comprehension on recall of informed consent information by low-income parents: a comparison of print, video, and computer-based presentations. Patient Education and Counseling 2004;53(2):205216. [PubMed: 15140461]

Carlsson ME, Strang PM. Facts, misconceptions, and myths about cancer. What do patients with gynecological cancer and the female public at large know? Gynecologic Oncology 1997;65:46-53. [PubMed: 9103390]

Carmona RH. Health Literacy: A National Priority. Journal of General Internal Medicine 2006;21:803.

Castro CM, Wilson C, Wang F, Schillinger D. Babel babble: physicians' use of unclarified medical jargon with patients. American Journal of Health Behavior 2007;31(Suppl 1):S85-95. [PubMed: 17931142]

Corston R, Colman AM. Modality of Communication and Recall of Health-Related Information. Journal of Health Psychology 1997;2:185-194.

Davis TC, Dolan NC, Ferreira MR, Tomori C, Green KW, Sipler AM, et al. The role of inadequate health literacy skills in colorectal cancer screening. Cancer Investigation 2001;19(2):193-200. [PubMed: 11296623]

Fischhoff B. Why (Cancer) Risk Communication Can Be Hard. Journal of the National Cancer Institute Monographs 1999;25:7-13. [PubMed: 10854449]

Friedman DB, Corwin SJ, Dominick GM, Rose ID. African American Men's Understanding and Perceptions About Prostate Cancer: Why Multiple Dimensions of Health Literacy are Important in Cancer Communication. Journal of Community Health 2009;34(5):449-460. [PubMed: 19517223]

Gallup Organization. Gallup poll (Report). Storrs, CT: Roper Center for Public Opinion Research; 2002.

Gantz W, Wang Z. Coverage of cancer in local television news. Journal of Cancer Education 2009;24 (1):65-72. [PubMed: 19259868]

Graesser AC, Millis KK, Zwaan RA. Discourse comprehension. Annual Review of Psychology 1997;48:163-189.

Hesse BW. Cancer communication: Status and future directions. Journal of Health Communication 2009;14(Suppl1):109-127. [PubMed: 19449274]

Nielsen-Bohlman, L.; Panzer, AM.; Kindig, DA., editors. The Institute of Medicine of the National Academiesa. Health literacy: A prescription to end confusion. Washington, D.C: The National Academies Press; 2004.

Jewett JJ, Hibbard JH. Comprehension of quality care indicators: differences among privately insured, publicly insured, and uninsured. Health Care Financing Review 1996;18(1):75-94. [PubMed: 10165038]

Kaphingst KA, Rudd RE, Dejong W, Daltroy LH. Comprehension of information in three direct-toconsumer television prescription drug advertisements among adults with limited literacy. Journal of Health Communication 2005;10(7):609-619. [PubMed: 16278198]

Kilbridge KL, Fraser G, Krahn M, Nelson EM, Conaway M, Bashore R, et al. Lack of comprehension of common prostate cancer terms in an underserved population. Journal of Clinical Oncology 2009;27 (12):2015-2021. [PubMed: 19307512]

Kintsch W. The role of knowledge in discourse comprehension: a construction-integration model. Psychological Review 1988;95(2):163-182. [PubMed: 3375398]

Kintsch, W. Comprehension: A paradigm for cognition. New York: Cambridge University Press; 1998.

Klein WM, Stefanek ME. Cancer risk elicitation and communication: lessons from the psychology of risk perception. CA A Cancer Journal for Clinicians 2007;57(3):147-167. [PubMed: 17507441]

Kreuter M. Dealing with competing and conflicting risks in cancer communication. Journal of the National Cancer Institute Monographs 1999;25:27-35. [PubMed: 10854454]

Lerman C, Schwartz M. Adherence and psychological adjustment among women at high risk for breast cancer. Breast Cancer Research and Treatment 1993;28(2):145-155. [PubMed: 8173067]

Mayer RE, Hegarty M, Mayer S, Campbell J. When static media promote active learning: annotated illustrations versus narrated animations in multimedia instruction. Journal of Experimental Psychology Applied 2005;11(4):256-265. [PubMed: 16393035] 
Morris NS, MacLean CD, Chew LD, Littenberg B. The Single Item Literacy Screener: evaluation of a brief instrument to identify limited reading ability. BMC Family Practice 2006;7:21. [PubMed: 16563164]

Nekhlyudov L, Braddock CH 3rd. An approach to enhance communication about screening mammography in primary care. Journal of Women's Health (Larchmt) 2009;18(9):1403-1412.

Niederdeppe J, Frosch DL, Hornik RC. Cancer News Coverage and Information Seeking. Journal of Health Communications 2008;131(2):181-199.

Pribble JM, Goldstein KM, Fowler EF, Greenberg MJ, Noel SK, Howell JD. Medical news for the public to use? What's on local TV news. American Journal of Managed Care 2006;12(3):170-176. [PubMed: 16524349]

Reyna VF. A theory of medical decision making and health: fuzzy trace theory. Medical Decision Making 2008;28(6):850-865. [PubMed: 19015287]

Ripath, J.; SM, G.; CJ, W. PRISM Readability Toolkit. Seattle: Group Health Research Institute; 2007.

Roche RA, Stovall CE, Suarez L, Goldman DA, Wright SA, Mendez MC. Language differences in interpretation of breast cancer health messages. Journal of Cancer Education 1998;13(4):226-230. [PubMed: 9883782]

Rogers ES, Wallace LS, Weiss BD. Misperceptions of medical understanding in low-literacy patients: implications for cancer prevention. Cancer Control 2006;13(3):225-229. [PubMed: 16885919]

Rosenfeld L, Rudd R, Emmons K, Acevedo-Garcia D, Martin L, Buka S. Beyond reading alone: The relationship between aural literacy and asthma management. Patient Education Counseling. 201010.1016//pec2010.02.023

Roter DL, Erby L, Larson S, Ellington L. Oral literacy demand of prenatal genetic counseling dialogue: Predictors of learning. Patient Education and Counseling 2009;75(3):392-397. [PubMed: 19250792]

Roter DL, Erby LH, Larson S, Ellington L. Assessing oral literacy demand in genetic counseling dialogue: preliminary test of a conceptual framework. Social Science and Medicine 2007;65(7):1442-1457. [PubMed: 17614177]

Rubin D, Hafer T, Arata K. Reading and Listening to Oral-based Versus Literate-Based Discourse. Communication Education 2000;49(2):121-133.

Salant T, Ganschow PS, Olopade OI, Lauderdale DS. "Why take it if you don't have anything?" breast cancer risk perceptions and prevention choices at a public hospital. Journal of General Internal Medicine 2006;21(7):779-785. [PubMed: 16808782]

Savage SA, Clarke VA. Older women's illness representations of cancer: a qualitative study. Health Education Research 1998;13(4):529-544. [PubMed: 10345904]

Schofield PE, Butow PN. Towards better communication in cancer care: a framework for developing evidence-based interventions. Patient Education and Counseling 2004;55(1):32-39. [PubMed: 15476987]

Schroy PC 3rd, Glick JT, Robinson PA, Lydotes MA, Evans SR, Emmons KM. Has the surge in media attention increased public awareness about colorectal cancer and screening? Journal of Community Health 2008;33(1):1-9. [PubMed: 18080203]

Schwartzberg JG, Cowett A, VanGeest J, Wolf MS. Communication techniques for patients with low health literacy: a survey of physicians, nurses, and pharmacists. American Journal of Health Behavior 2007;31(Suppl 1):S96-104. [PubMed: 17931143]

Silverman E, Woloshin S, Schwartz LM, Byram SJ, Welch HG, Fischhoff B. Women's views on breast cancer risk and screening mammography: a qualitative interview study. Medical Decision Making 2001;21(3):231-240. [PubMed: 11386630]

Slovic, P. The perception of risk. London: Earthscan; 2000.

Southwell BG, Torres A. Connecting interpersonal and mass communication: Science news exposure, perceived ability to understand science, and conversation. Communication Monographs 2006;(73): 334-350.

Southwell BG, VB, Hwang Y, Yzer MC. Entertainment tonight? The value of informative TV news among U.S. viewers. Electronic News 2008;2:123-137.

Vernon SW. Risk perception and risk communication for cancer screening behaviors: a review. Journal of the National Cancer Institute Monographs 1999;(25):101-119. [PubMed: 10854465] 
Viswanath K. Science and society: the communications revolution and cancer control. National Review of Cancer 2005;5(10):828-835.

Wang Z, Gantz W. Health content in local television news. Health Communication 2007;21(3):213-221. [PubMed: 17567253]

Wang Z, Gantz W. Health content in local television news: a current appraisal. Health Communication 2010;25(3):230-237. [PubMed: 20461608]

Weiss B, Reed R, Kligman E. Literacy skills and communication methods of low-income older persons. Patient Education and Counseling 1995;25:109-119. [PubMed: 7659623]

Williams MV, Davis T, Parker RM, Weiss BD. The role of health literacy in patient-physician communication. Family Medicine 2002;34(5):383-389. [PubMed: 12038721]

Wilson EA, Wolf MS. Working memory and the design of health materials: a cognitive factors perspective. Patient Education and Counseling 2009;74(3):318-322. [PubMed: 19121915]

Yanovitzky I, Blitz CL. Effect of media coverage and physician advice on utilization of breast cancer screening by women 40 years and older. Journal of Health Communication 2000;5(2):117-134. [PubMed: 11010345] 
Table 1

\section{Video Clip Description}

\begin{tabular}{|c|c|c|c|c|}
\hline Title & Source & Time & Story Format & Summary \\
\hline 1. Cancer Causes Identified & CBS News & $2 \min 29 \mathrm{sec}$ & $\begin{array}{l}\text { News story. Medical editor } \\
\text { summarizes new report, author or } \\
\text { report comments. }\end{array}$ & $\begin{array}{l}\text { Refers to recently released research } \\
\text { which is reported to have identified } \\
\text { obesity as a major risk factor for } \\
\text { certain cancers. Also refers to } \\
\text { specific dietary risk factors. }\end{array}$ \\
\hline 2. Desk Jobs and Prostate Cancer & $\mathrm{CNN}$ & $2 \mathrm{~min} 12 \mathrm{sec}$ & $\begin{array}{l}\text { News story. News anchor talks to } \\
\text { medical correspondent who } \\
\text { summarizes report. }\end{array}$ & $\begin{array}{c}\text { Refers to recently released research } \\
\text { which is reported to have found a } \\
\text { relationship between sedentary jobs } \\
\text { and prostate cancer. }\end{array}$ \\
\hline 3. Mammogram Controversy & CBS News & $2 \mathrm{~min} 16 \mathrm{sec}$ & $\begin{array}{l}\text { News story. News anchor } \\
\text { interviews expert (breast cancer } \\
\text { surgeon, director of local breast } \\
\text { cancer center) }\end{array}$ & $\begin{array}{l}\text { Refers to recently released report } \\
\text { which is reported to encourage } \\
\text { women to talk to their physicians } \\
\text { about breast cancer screening at age } \\
40 \text {, in contrast to prior report } \\
\text { (referred to as having been } \\
\text { discussed previously) which calls } \\
\text { for women age } 40 \text { and older to have } \\
\text { routine mammograms. }\end{array}$ \\
\hline 4. Colorectal Cancer & NIH Website & $2 \mathrm{~min} 43 \mathrm{sec}$ & $\begin{array}{l}\text { Informational story. A National } \\
\text { Cancer Institute expert (on-screen) } \\
\text { talks about screening; a narrator } \\
\text { paraphrases some facts comments. }\end{array}$ & $\begin{array}{l}\text { Talks about the prevalence of } \\
\text { polyps, colorectal cancer, the } \\
\text { importance and value of screening, } \\
\text { and offers guidelines for when } \\
\text { screening should occur. }\end{array}$ \\
\hline 5. Preventing Cervical Cancer & $\mathrm{CNN}$ & $1 \mathrm{~min} 15 \mathrm{sec}$ & $\begin{array}{l}\text { Personal story. A woman describes } \\
\text { her personal experience, the } \\
\text { narrator and a physician provide } \\
\text { additional factual information. }\end{array}$ & $\begin{array}{l}\text { Refers to the woman's specific } \\
\text { symptoms and treatment; causes } \\
\text { and prevention of cervical cancer. }\end{array}$ \\
\hline 6. Understanding Skin Cancer & WebMD & $2 \mathrm{~min} 43 \mathrm{sec}$ & $\begin{array}{l}\text { Personal story. A woman describes } \\
\text { her personal experience with skin } \\
\text { cancer; the narrator and two } \\
\text { physicians provide additional } \\
\text { factual information. }\end{array}$ & $\begin{array}{l}\text { Describes types of skin cancer, the } \\
\text { treatment the woman in the clip } \\
\text { underwent, and steps she is } \\
\text { currently taking to prevent } \\
\text { recurrence, the ABCD method of } \\
\text { determining whether a mole should } \\
\text { be examined. }\end{array}$ \\
\hline
\end{tabular}


Table 2

Example of coding scheme and application of codes to interviewee responses

\begin{tabular}{|l|l|l|l|l|}
\hline Video Text & $\begin{array}{l}\text { Coding } \\
\text { scheme: } \\
\text { "gist" } \\
\text { category }\end{array}$ & $\begin{array}{l}\text { Example of } \\
\text { interviewees } \\
\text { statement coded } \\
\text { in this category }\end{array}$ & $\begin{array}{l}\text { Coding scheme: } \\
\text { specific } \\
\text { subcategory }\end{array}$ & $\begin{array}{l}\text { Example of interviewee statement coded in this } \\
\text { subcategory }\end{array}$ \\
\hline $\begin{array}{l}\text { About seventy } \\
\text { percent of colon } \\
\text { cancer occurs in } \\
\text { people older than } \\
60 \text { years of age. }\end{array}$ & $\begin{array}{l}\text { Most colon } \\
\text { cancer occurs } \\
\text { in older } \\
\text { people. }\end{array}$ & $\begin{array}{l}\text { Colon cancer... } \\
\text { occurs in the latter } \\
\text { years. }\end{array}$ & $\begin{array}{l}70 \% \text { of colon } \\
\text { cancer occurs in } \\
\text { people older than } \\
60\end{array}$ & None \\
\hline $\begin{array}{l}\text { Up to 30, 40 } \\
\text { percent of } \\
\text { individuals over } \\
\text { age 60 have them } \\
\text { [polyps]. }\end{array}$ & $\begin{array}{l}\text { Polyps are } \\
\text { common in } \\
\text { older people }\end{array}$ & None & $\begin{array}{l}30 \text { to 40\% of } \\
\text { people older than } \\
60 \text { have polyps. }\end{array}$ & $\begin{array}{l}\text { The older we get, especially after 60, 30 to 40\% of us do have } \\
\text { polyps. } \\
\text { to of the population has polyps [inaccurate due reference }\end{array}$ \\
\hline
\end{tabular}


Table 3

Participant Characteristics

\begin{tabular}{|c|c|c|}
\hline & $\mathbf{N}$ & $\%$ \\
\hline \multicolumn{3}{|l|}{ Gender } \\
\hline Female & 23 & 52 \\
\hline Male & 21 & 48 \\
\hline \multicolumn{3}{|l|}{ Age } \\
\hline $40-49$ & 10 & 23 \\
\hline $50-59$ & 15 & 34 \\
\hline $60-70$ & 19 & 43 \\
\hline \multicolumn{3}{|l|}{ Race } \\
\hline White & 23 & 52 \\
\hline Black/African American & 6 & 14 \\
\hline Asian/Pacific Islander & 11 & 25 \\
\hline Other race & 4 & 9 \\
\hline \multicolumn{3}{|l|}{ Ethnicity } \\
\hline Hispanic & 3 & 7 \\
\hline \multicolumn{3}{|l|}{ Education } \\
\hline High school or less & 2 & 5 \\
\hline Some college & 20 & 45 \\
\hline Bachelors degree & 10 & 23 \\
\hline Graduate degree & 12 & 27 \\
\hline \multicolumn{3}{|c|}{ Single Item Literacy Screener: Need Help Reading Written Material (Morris, MacLean, Chew, \& Littenberg, 2006} \\
\hline Never & 16 & 36 \\
\hline Rarely & 23 & 52 \\
\hline Sometimes & 3 & 7 \\
\hline Often & 1 & 2 \\
\hline Always & 1 & 2 \\
\hline
\end{tabular}


Table 4

Definitions of key words and phrases

\begin{tabular}{|c|c|}
\hline $\begin{array}{l}\text { Sentence from video clip. Key word is bolded. } \\
\text { Definition }\end{array}$ & Examples of participants' definitions \\
\hline $\begin{array}{l}\text { "Prevention is key." } \\
\text { To keep from happening or existing. }{ }^{1}\end{array}$ & $\begin{array}{l}\text { "How to stop something from occurring" } \\
\text { "Things to do to stop you from getting the disease" } \\
\text { "To eat healthy and live a healthy lifestyle" } \\
\text { "Watching out and being careful" } \\
\text { "To avoid trouble, to avoid things that have been proven to induce the growth of } \\
\text { cancer in our bodies" } \\
\text { "We can avoid cancer if we avoid the following: alcohol, smoking, etc." } \\
\text { "Stop taking unnecessary risks with your body" } \\
\text { "Doing the wrong thing" }\end{array}$ \\
\hline $\begin{array}{l}\text { "500 doctors, } 7,000 \text { clinical trials provide evidence on what } \\
\text { causes cancer, what we should eat, what we shouldn't eat." } \\
\text { Something that furnishes proof. } 1\end{array}$ & $\begin{array}{l}\text { "It's proof of something" } \\
\text { "Empirical research to show that there is a relationship between and activity and } \\
\text { cancer" } \\
\text { "What was determined through the study" } \\
\text { "Factual" } \\
\text { "...hard core facts. It means it's true..." } \\
\text { "Data collected over time" } \\
\text { "Something that has been measured, not just anecdotal statements, but it is } \\
\text { numbers and data backing up whatever claim they are making" } \\
\text { "Clinical trials" } \\
\text { "Reading, talking with people, studying" } \\
\text { "Nothing is } 100 \% \text { true, they are looking at the data and drawing conclusions } \\
\text { from the data that is out there, everything is implied, they don't know anything } \\
\text { for sure." }\end{array}$ \\
\hline $\begin{array}{l}\text { "Men with desk jobs are more at risk for prostate cancer." } \\
\text { In a state or condition marked by a high level of risk or } \\
\text { susceptibility. } 1\end{array}$ & $\begin{array}{l}\text { "higher chance" } \\
\text { "more likely to get" } \\
\text { "prone to" } \\
\text { "tend to" } \\
\text { "probability is much higher" } \\
\text { "likely" } \\
\text { "gossibility" } \\
\text { "more opportunities" }\end{array}$ \\
\hline $\begin{array}{l}\text { "Men with sedentary jobs are more likely to have developed } \\
\text { prostate cancer." } \\
\text { Doing or requiring much sitting, not physically active. }{ }^{1}\end{array}$ & $\begin{array}{l}\text { "inactive" } \\
\text { "not moving around" } \\
\text { "stationary" } \\
\text { "sitting around all day, not being active" } \\
\text { "sitting down, being lazy" } \\
\text { "more prone to sit down than stand up" } \\
\text { "doing as little as possible physically" }\end{array}$ \\
\hline $\begin{array}{l}\text { Some women will undergo a biopsy after having a } \\
\text { mammogram, and we learn a lot from that biopsy. } \\
\text { The removal and examination of tissue, cells, or fluids from the } \\
\text { living body. } 1\end{array}$ & $\begin{array}{l}\text { "Sample of suspect tissue to see if they have cancer" } \\
\text { "Removing a section for examination, usually for cancer." } \\
\text { "Take a portion of the breast, where there was a lump, to see if it is malignant or } \\
\text { not." } \\
\text { "More information - from a tissue sample." } \\
\text { "Test beyond a mammogram." } \\
\text { "Test where they actually put a needle in, x-ray under a microscope and exam } \\
\text { it" } \\
\text { "Taking a piece of whatever the infection is to find out if it's good or bad." } \\
\text { "A way of pulling tissue." }\end{array}$ \\
\hline $\begin{array}{l}\text { "We learn a lot of information about a woman's true risk of } \\
\text { breast cancer from that pathology." } \\
\text { The study of the essential nature of diseases and especially of } \\
\text { the structural and functional changes produced by them; the } \\
\text { structural and functional deviations from the normal that } \\
\text { constitute disease or characterize a particular disease. }{ }^{1}\end{array}$ & $\begin{array}{l}\text { "testing; discovering whether it's positive or negative" } \\
\text { "testing it; see if there are cancer cells, see how quickly they are growing testing; } \\
\text { tell if there is an abnormality" } \\
\text { "Looking at the tissue" } \\
\text { "Test it - fluid - to see what the risk factors are" }\end{array}$ \\
\hline $\begin{array}{l}\text { It is important to get screened for colorectal cancer because } \\
\text { many cases of colorectal cancer might be prevented or cured } \\
\text { if found early enough. } \\
\text { Checking for disease when there are no symptoms. Since } \\
\text { screening may find diseases at an early stage, there may be a } \\
\text { better chance of curing the disease. Screening can also include }\end{array}$ & $\begin{array}{l}\text { "It's like a test. It just means they are checking for something." } \\
\text { "testing" } \\
\text { "having a colonoscopy." } \\
\text { "check up" } \\
\text { "checked out, medically probed ... to alleviate the possibility of you getting or } \\
\text { someone catching, catching like it's a cold, getting it." }\end{array}$ \\
\hline
\end{tabular}




\begin{tabular}{|c|c|}
\hline $\begin{array}{l}\text { Sentence from video clip. Key word is bolded. } \\
\text { Definition }\end{array}$ & Examples of participants' definitions \\
\hline \multicolumn{2}{|l|}{$\begin{array}{l}\text { checking for a person's risk of developing an inherited disease } \\
\text { by doing a genetic test. }{ }^{2}\end{array}$} \\
\hline $\begin{array}{l}\text { "If found in its early stages, colorectal cancer is about } 90 \% \\
\text { curable." } \\
\text { Early stage cancer: A term used to describe cancer that is early } \\
\text { in its growth, and may not have spread to other parts of the } \\
\text { body. What is called early stage may differ between cancer } \\
\text { types. }{ }^{2}\end{array}$ & $\begin{array}{l}\text { "That would be the polyp stage, which would be stage } 1 \text {, which would be } \\
\text { precancerous lesions ... it's not cancer yet but it could develop into cancer." } \\
\text { "when they're just beginning to develop." } \\
\text { "early stage is the very beginning." } \\
\text { "before it spreads." } \\
\text { "like the first, when those bad cells start forming" } \\
\text { "The chances of cure are based on stages, if it's stage 1, just one spot, you can } \\
\text { be cured." } \\
\text { "It's just beginning. You're getting the growth, and they're just beginning to } \\
\text { catch hold and do their thing. So you are catching them before they get attached } \\
\text { to you." } \\
\text { "Still within the colon and hasn't gone to higher stages." } \\
\text { "Discovered at a certain time in your life." }\end{array}$ \\
\hline $\begin{array}{l}\text { "She learned that cervical cancer is caused by the Human } \\
\text { Papilloma Virus or HPV." } \\
\text { A member of a family of viruses that can cause abnormal tissue } \\
\text { growth (for example, genital warts) and other changes to cells. } \\
2\end{array}$ & $\begin{array}{l}\text { "it's a virus that causes cervical cancer in a woman and is sexually transmitted" } \\
\text { "virus" } \\
\text { "...it's a cancer transmitted and received and it grows primarily in the uterus" } \\
\text { "herpes" }\end{array}$ \\
\hline $\begin{array}{l}\text { "The American Cancer Society recommends women be } \\
\text { screened with a Pap test within three years of becoming } \\
\text { sexually active and no later than the age of } 21 . " \\
\text { A procedure in which cells are scraped from the cervix for } \\
\text { examination under a microscope. It is used to detect cancer } \\
\text { and changes that may lead to cancer. }\end{array}$ & $\begin{array}{l}\text { "A scraping of the lining of the cervix to see if there is cancer present" } \\
\text { "It detects whether there is cervical cancer" } \\
\text { "the test they do to detect HPV" } \\
\text { "They clip tissue or something, and they send it off to the lab to be screened for } \\
\text { cancer" } \\
\text { "...they get a smear test of the fluids in the birthing canal" } \\
\text { "woman's test; I have no idea" } \\
\text { "blood test" }\end{array}$ \\
\hline $\begin{array}{l}\text { If you are in a high risk group, you should limit sun exposure } \\
\text { and examine your skin once a month. } \\
\text { In danger, subject to hazard. }{ }^{3}\end{array}$ & $\begin{array}{l}\text { "at risk that is above the average" } \\
\text { "more likely" } \\
\text { "more prone to get it" } \\
\text { "possibility of getting cancer is high" } \\
\text { "probability of getting whatever you're talking about it very high" } \\
\text { "very much in danger of" } \\
\text { at risk, like being an alcoholic or drug addict" }\end{array}$ \\
\hline $\begin{array}{l}\text { "Basal cell skin cancers are less likely to be fatal than } \\
\text { malignant melanoma." } \\
\text { Cancerous. Malignant tumors can invade and destroy nearby } \\
\text { tissue and spread to other parts of the body. }{ }^{2}\end{array}$ & $\begin{array}{l}\text { "a cancerous growth which unfortunately can metastasize and attach itself to } \\
\text { other organs or other tissues" } \\
\text { "it can spread rapidly" } \\
\text { "cancerous" } \\
\text { "real cancer" } \\
\text { "active; you really have the cancer" } \\
\text { "Bad. Overgrowth" } \\
\text { "fatal" } \\
\text { "maybe-ish; not necessarily" }\end{array}$ \\
\hline
\end{tabular}

${ }^{1}$ In Merriam-Webster's Dictionary. Retrieved from http://www.merriam-webster.com/.

2 In National Cancer Institute Dictionary of Cancer Terms. Retrieved from http://www.cancer.gov/dictionary/.

3 In Oxford English Dictionary. Retrieved from http://dictionary.oed.com.

For each word or phrase, some participants responded "don't know" and did not provide any definition. 